\title{
PENGARUH RASIO KEUANGAN TERHADAP NILAI PERUSAHAAN PADA PT. ASTRA GRAPHIA Tbk.
}

\author{
Fakriatun Baiti ${ }^{1}$ \\ M.Rimawan ${ }^{2 *}$ \\ ${ }^{1}$ Sekolah Tinggi Ilmu Ekonomi (STIE) Bima \\ Email : fakriatunbaiti@gmail.com \\ ${ }^{2}$ Sekolah Tinggi Ilmu Ekonomi (STIE) Bima \\ *Corresponding Author Email : rimawan111@gmail.com
}

\begin{abstract}
Abstrak
This study raises issues related to DER, ROE, CR and PER where these 4 variables have a large influence on firm value $(P B V)$, resulting in research objectives, namely to determine the effect of DER (Debt to Equity Ratio, ROE (Return on Equity, CR (Current Ratio) and PER (Price Earning Ratio), (PER) to firm value $(P B V)$ either partially or simultaneously at PT. Astra Graphia Tbk. for the period 2005-2019. This research is an associative study with a population of 30 years and a sample of 15 years in This research uses 2 data collection techniques, namely literature study and documentation using 3 methods of analysis, namely classical assumption test, multiple linear regression analysis and hypothesis testing. The results show that partially DER (Debt to Equity Ratio), ROE (Return on Equity) and CR (Current Ratio) has no effect on firm value while PER (Price Earning Ratio) has an effect on firm value an (PBV) at PT. Astra Graphia Tbk. while simultaneously DER (Debt to Equity Ratio), ROE (Return on Equity) and CR (Current Ratio), PER (Price Earning Ratio) affect firm value (PBV).
\end{abstract}

Keywords : Rasio Keuangan, Nilai Perusahaan, Laporan Keuangan

\section{PENDAHULUAN}

Siapa yang tidak menyadari perkembangan dunia usaha saat ini baik dari kalagan pengusaha maupun masyarakat biasa, dulu masyrakat biasa sulit untuk terjun keduni investasi seperti saham. Tetapi seiring berkembangnya dunia usaha saat ini maka semakin mudah pula semuanya diakses oleh masyarakat. Karena perkembangan dunia usaha yang cukup signifikan didunia penggusaha menimbulkan persaingan sengit antara pengusaha satu dengan penggusaha lainnya. Dimana para pemimpin dan manajer perusahaan dituntut untuk mampu berinovasi dalam produk dan cekatan dalam mengelola keuangan perusahaan. Untuk mendukung hal itu biasanya para pemimpin perusahaan menilai kinerja mereka dari nilai perusahaan itu sendiri. Kenapa harus nilai perusahaan? Karena pada dasarnya nilai perusahaan yang tinggi mencerminkan nilai saham yang tinggi dan nilai saham yang tinggi mencerminkan bahwa saham tersebut diperebutkan dikalangan investor.

Seorang investor selalu menjadikan sebuah nilai perusahaan sebagai acuan untuk melihat performan perusahaan tersebut Menurut jurnal (Purwanto \& Agustin, 2017). Sebuah perusahaan dengan presentasi keuangan yang bagus bisa memperngaruhi calon investor untuk menanamkan modal mereka sehingga menyebabkan naiknya nilai pasar saham perusahaan dan bila nilai sebuah pasar saham naik bukan hanya memberikan angin sejuk untuk perusahaan tetapi juga memberikan angin sejuk untuk untuk para pemegang saham Menurut penelitian (Luthfiah \& Suherman, 2018). Salah satu acuan untuk menetapkan nilai perusahaan yaitu dengan memakai PBV (Price to Book Value). PBV adalah nilai yang mengambarkan seberapa besar hasil yang diperoleh sebuah perusahaan dalam mengelola modal dari investor, perusahaan dengan nilai akhir PBV yang tinggi berarti berhasil untuk memenangkan hati para investor karena berhasil menghasilkan laba untuk para pemengang saham (Salim \& Susilowati, 2020).

Ada berbagai macam cara untuk menganalisis yang bisa dipilih dan dipilah oleh para investor. Yang salah satunya yaitu secara sederhananya dengan teknik studi yang berkarakter fundamental, analisi technical, analisi economy dan analisis financial ratio. Fundamental artinya ikatan informasi dengan kondisi perseroan yang suatu ketika akan dipakai dalam sebuah laporan keuangan karena ini adalah salah 
satu standar kinerja perusahaan. Ada 4 teknik analisis rasio keuangan yang kita pakai dalam penelitian kali ini antara lain yaitu profitability ratio yang diwakilkan dengan ROE (Return on Equty), liquidity ratio yang diwakili dengan CR (Current Ratio), solvency ratio yang diwakili dengan DER (Debt to Equity Ratio) dan growt opportunity ratio yang diwakili dengan PER (Price Earning Ratio).

ROE (Return on Equty) mengambarkan sebagai salah satu profitability ratio yang mampu memperkirakan seberapa besar kekuatan perusahaan dapat memanifestasikan laba dari para investor perusahaan tersebut. Rasio yang paling mudah digunakan dalam menganalisis laporan keuangan yaitu Current Ratio atau biasa disebut rasio lancar ini adalah standar rasio untuk melihat besar kecilnya nilai mengambarkan seberapa besar ikatan antara jumlah modal dari perusahaan dengan pinjaman jangka panjang yang diberikan oleh para kreditur. PER (Price Earning Ratio) adalah sebuah rasio yang memgambarkan perbandingan antara harga saham dengan laba yang di hasilkan oleh saham tersebut.

Grafik 1

Data empiris mengenai DER,ROE,CR,PER,PBV

PT. Astra Graphia Tbk. periode 2005-2019

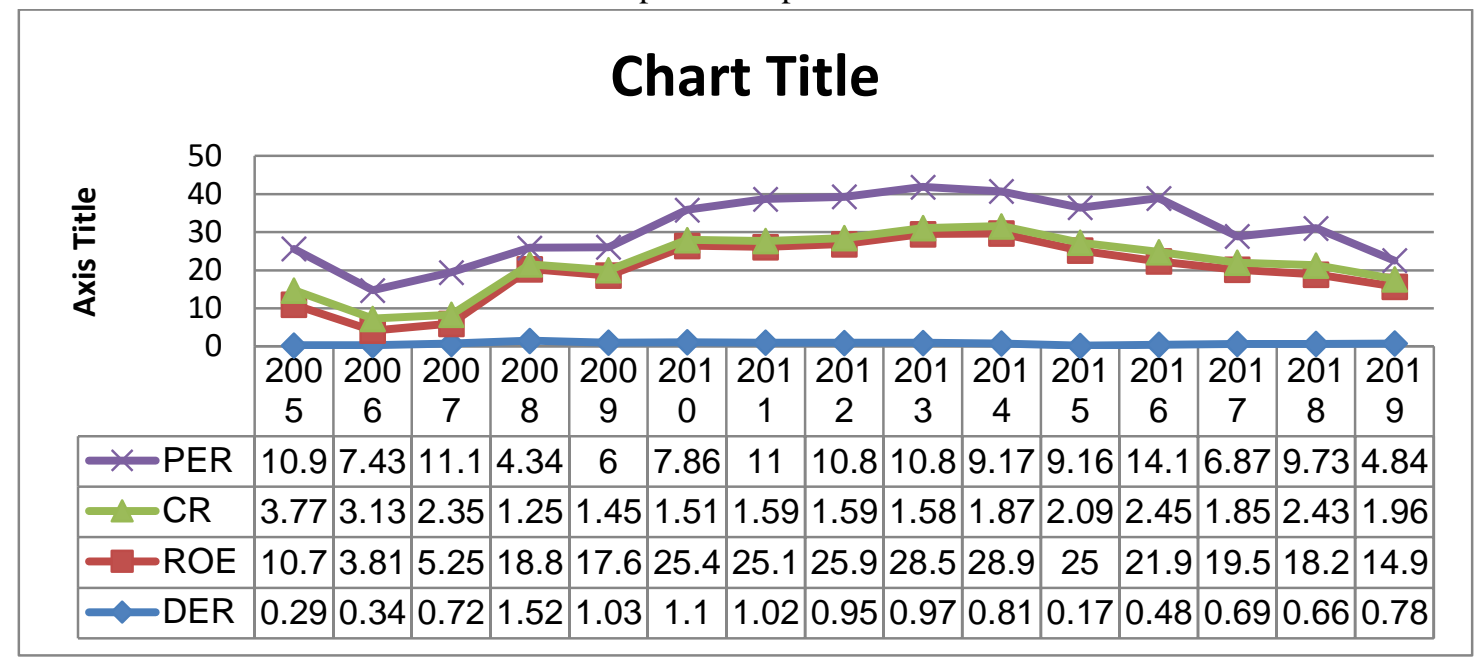

Sumber: data diolah

Dapat kita perhatikan secara saksama data diatas menunjukan bahwa adanya fluktuasi pada setiap nilai pertengahan baik dari CR (Current Ratio), ROE (Return on Equty), DER (Debt to Equity Ratio), PER (Price Earning Ratio) terhadap nilai perusahaan pada PT. Astra Graphia Tbk. periode 2005-2019. Nilai DER yang baik adalah DER dengan angka dibawah 1 Menurut (Harahap, 2018) tetapi pada tahun 20082011 nilai DER melebihi angka 1 yang artinya DER dalam keadaan tidak baik hal ini disebabkan karena nilai liabilitas yang lebih besar dari pada ekuitas, sedangkan di tahun 2012 sampai 2019 Nilai DER berada dibawah 1 dan itu menunjukan bahwa nilai liabilitas itu mengalami penurunan atau Modal perusahaan bisa memenuhi/membiayai liabilitas. Nilai ROE Ideal adalah diatas 8,32\% Menurut (Lukviarman, 2006) tetapi pada tahun 2006-2007 nilai ROE di bawah standar hal ini disebabkan karena menurunya laba bersih, sedangkan tahun 2008 sampai 2019 Nilai ROE berada diatas standar yang ditetapkan ini menunjukan laba bersih mengalami peningkatan.

Nilai CR yang baik adalah di atas 1,0 kali Menurut Menurut (Nurlia \& Juwari, 2019) dan selama periode 15 tahun tersebut nilai CR dalam keadaan baik ini ditunjukan dengan nilai CR yang berada di atas 1 ini berarti kemampuan asset lancar perusahaan mampu menutupi kewajiban lancar. Nilai PER yang ideal adalah 20-25 kali lipat dari pendapatan (Wahyudiono, 2014) dan nilai PER selama 15 tahun dibawah ideal. Untuk PBV standar yang baik apabila mampu mennunjukan nilai lebih dari 1 untuk perusahaan PT. Astra Graphia Tbk. selama 15 tahun terakhir menunjukan trend yang sangat baik karena nilai PBV berada diatas nilai standar yang ditetapkan Menurut (Murhadi, 2015), Karena menurut pendapat saya nilai perusahaan itu penting sehingga saya ingin mengetahui dengan jelas apa saja variable yang mempengaruhi nilai 
perusahaan sehingga saya memutuskan untuk meneliti dengan judul penelitian pengaruh Debt to Equity Ratio, Return on Equity, Current Ratio dan Price Earning Ratio terhadap nilai perusahaan pada PT. Astra Graphia Tbk. yaitu:

Berdasarkan judul yang dipaparkan oleh peneliti di atas maka dapat di tarik tujuan dari penelitian

1. Untuk mengetahui adakah pengaruh DER (Debt To Equity Ratio) secara parsial terhadap nilai perusahaan pada PT. Astra Graphia Tbk. tahun 2005-2019

2. Untuk mengetahui adakah pengaruh ROE (Return On Equity) secara parsial terhadap nilai perusahaan pada PT. Astra Graphia Tbk. tahun 2005-2019

3. Untuk mengetahui adakah pengaruh CR(Current Ratio) secara parsial terhadap nilai perusahaan pada PT. Astra Graphia Tbk. tahun 2005-2019

4. Untuk mengetahui adakah pengaruh PER (Price Earning Ratio) secara parsial terhadap nilai perusahaan pada PT. Astra Graphia Tbk. tahun 2005-2019

5. Untuk mengetahui Adakah pengaruh PER (Price Earning Ratio), ROE (Return On Equity), DER (Debt To Equity Ratio) dan CR (Current Ratio) secara simultan terhadap Nilai Perusahaan pada PT. Astra Graphia Tbk. tahun 2005-2019.

\section{KAJIAN PUSTAKA DAN PENGEMBANGAN HOPOTESIS}

DER (Debt To Equity Ratio)

DER (Debt To Equity Ratio) artinya yaitu "sebuah ratio yang mengambarkan sampai seberapa besar perusahaan dapat meminimalisir hutangnya untuk pihak diluar dari modal perusahaan sendiri, semakin kecil nilai dari DER maka rasio dikatakan bagus" DER yang ideal adalah DER dengan angka dibawah 1 namun DER dengan angka diatas 1 artinya dalam kondisi tidak baik karena kewajiban lebih besar dari pada modal bersih (Harahap, 2018). Menurut (Harahap, 2018) rumus Debt to Equity Ratio sebagai berikut:

$$
\text { Rumus DER }=\frac{\text { Total Liability }}{\text { Total Equity }}
$$

\section{ROE (Return On Equity)}

ROE (Return On Equity) menunjukan seberapa mampu sebuah perusahaan mendapatkan laba sesudah dibebankan pajak dari mengalokasikan modal sendiri sebuah perusahaan Menurut (Nurlia dan Trifina, 2018). ROE dikatakan baik jikalau nilainya di atas 8,32\% tetapi jika di bawah 8,32\% maka dikatakan tidak baik (Lukviarman, 2006). Menurut (Fahmi, 2015) rumus Return on Equity sebagai berikut:

$$
\text { Rumus ROE }=\frac{\text { Earning After Taxes }}{\text { Total Equity }}
$$

\section{PER (Price Earning Ratio)}

PER (Price Earning Ratio) yaitu sebuah rasio yang mengambarkan perbedaan antara penghasilan yang masuk dengan nilai dari saham di tawarkan". Nilai PER yang ideal adalah 20-25 kali lipat dari pendapatan (Wahyudiono, 2014). Menurut (Fahmi, 2015) rumus Price Earning Ratio sebagai berikut:

$$
\text { Rumus PER }=\frac{\text { Harga Perlembar Saham }}{\text { Laba Perlembar Saham }}
$$

\section{CR (Current Ratio)}

CR (Current Ratio) merupakan rasio yang mengambarkan kemampuan current asset sebuah perusahaan yang bisa dipakai untuk memenuhi Current Liabilities. CR dikatakan ideal jika di atas 1,0 kali, jika dibawah 1,0 kali maka dikatakan buruk tetapi jika lebih dari 3 kali maka bisa jadi perusahaan tersebut kurang efisien dalam mengalokasikan aktiva lancar (Nurlia \& Juwari, 2019). Menurut (Murhadi, 2015) rumus Current Ratio sebagai berikut :

$$
\text { Rumus CR }=\frac{\text { Aktiva lancar }}{\text { Hutang lancar }}
$$




\section{PBV (Price to Book Value)}

PBV (Price to Book Value) merupakan ratio yang mengambarkan perbedaan antara market place saham dan nilai equity book yang telah dilampirkan pada financial position" Nilai ideal PBV adalah dibawah 1 tetapi pada pratikny Nilai PBV yang ideal menurul investor adalah di atas 1 (Murhadi, 2015). Menurut (Murhadi, 2015). Rumus Price Book Value sebagai berikut:

$$
\text { Rumus PBV }=\frac{\text { Harga saham }}{\text { Nilai buku saham }}
$$

\section{Pengembangan Hipotesis}

- Hipotesis 1

$\mathrm{H}_{\mathrm{a}}: \beta_{1} \neq 0$ : DER (Debt To Equity Ratio) berpengaruh secara parsial terhadap nilai perusahaan pada PT. Astra Graphia Tbk. (sesuai dengan penelitian (Anggraini, 2015) Analisis pengaruh PER (Price Earning Ratio), DER (Debt To Equity Ratio), ROA (Return On Asset), CR (Current Ratio) dan Firm Size Terhadap Nilai Perusahaan (PBV) pada perusahaan sektor estate dan building construction yang terdaftar di bursa efek Indonesia)

$\mathrm{H}_{0}: \beta_{1}=0$ : DER (Debt To Equity Ratio) tidak berpengaruh secara parsial terhadap nilai perusahaan pada PT. Astra Graphia Tbk. (sesuai dengan penelitian (Anggraini, 2015) Analisis pengaruh PER (Price Earning Ratio), DER (Debt To Equity Ratio), ROA (Return On Asset), CR (Current Ratio) dan Firmsize Terhadap Nilai Perusahaan (PBV) pada perusahaan sektor estate dan building construction yang terdaftar di bursa efek Indonesia)

- Hipotesis 2

$\mathrm{H}_{\mathrm{a}}: \beta_{2} \neq 0 \quad$ : ROE (Return On Equity) berpengaruh secara parsial terhadap nilai perusahaan pada PT. Astra Graphia Tbk. (sesuai dengan penelitian (Arif, 2015) Pengaruh struktur modal, ROE (Return On Equity),Likuiditas,dan Growth Opportunity terhadap nilai perusahaan pada perusahaan jasa yang terdaftar di bursa efek indonesia)

$\mathrm{H}_{0}: \beta_{2}=0$ : ROE (Return On Equity) tidak berpengaruh secara parsial terhadap nilai perusahaan pada PT. Astra Graphia Tbk. (sesuai dengan penelitian (Haerudin \& Marcelia, Pengaruh Stuktur Modal Profitabilitas dan Pertumbuhan Perusahaan pada Sektor Perusahaan Perbankan yang terdaftar di BEI 2013-2016, 2019) Pengaruh struktur modal, profitabilitas dan pertumbuhan perusahaan terhadap nilai perusahaan pada perusahaan perbankan yang terdaftar di bursa efek Indonesia)

- Hipotesis 3

$\mathrm{H}_{\mathrm{a}}: \beta_{3} \neq 0 \quad$ : CR (Current Ratio) berpengaruh secara parsial terhadap nilai perusahaan pada PT. Astra Graphia Tbk. (sesuai dengan penelitian (Anggraini, 2015)Analisis pengaruh PER (Price Eraning Ratio), DER (Debt To Equity Ratio), ROA (Return On Equity), CR (Current Ratio) dan Firm size Terhadap Nilai Perusahaan (PBV) Pada perusahaan sektor estate dan building construction yang terdaftar di bursa efek Indonesia)

$\mathrm{H}_{0}: \beta_{3}=0:$ CR (Current Ratio) tidak berpengaruh secara parsial terhadap nilai perusahaan pada PT. Astra Graphia Tbk. (sesuai dengan penelitian (Haerudin \& Marcellia, 2019) Pengaruh struktur modal, profitabilitas dan pertumbuhan perusahaan terhadap nilai perusahaan pada perusahaan perbankan yang terdaftar di bursa efek Indonesia)

- Hipotesis 4

$\mathrm{H}_{\mathrm{a}}: \beta_{4} \neq 0 \quad$ :PER (Price Earning Ratio) berpengaruh secara parsial terhadap nilai perusahaan pada PT. Astra Graphia Tbk. (sesuai dengan penelitian (Arif, 2015) Pengaruh struktur modal, ROE (Return On Equity), Likuiditas, dan Growth Opportunity terhadap nilai perusahaan pada perusahaan jasa yang terdaftar di bursa efek indonesia)

$\mathrm{H}_{0}: \beta_{4}=0$ : PER (Price Earning Ratio) tidak berpengaruh secara parsial terhadap nilai perusahaan pada PT. Astra Graphia Tbk.

- $\quad$ Hipotesis 5

$\mathrm{H}_{\mathrm{a}}: \beta_{5} \neq 0$ : PER (Price Earning Ratio), ROE (Return On Equity), DER (Debt To Equity Ratio) dan CR (Current Ratio) berpengaruh secara simultan terhadap Nilai Perusahaan pada PT. Astra Graphia Tbk. 
$\mathrm{H}_{0}: \beta_{5}=0$ : PER (Price Earning Ratio), ROE (Return On Equity), DER (Debt To Equity Ratio) dan CR (Curret Ratio) tidak berpengaruh secara simultan terhadap Nilai Perusahaan pada PT. Astra Graphia Tbk.

\section{METODE PENELITIAN}

Penelitian ini adalah penelitian yang bermaksud meneliti ikatan antara beberapa variable yang biasa disebut dengan penelitian asosiatif (Sugiyono, 2017). Jumlah populasi dalam penelitian ini adalah 30 tahun (mulai tahun 1990 - 2020) dengan jumlah sampel penelitian yaitu 15 tahun (mulai tahun 2005-2019) dimana teknik pengambilan sampel tergantung dari kriteria yang ditetapkan sesuai dengan kebutuhan peneliti Menurut (Sugiyono, 2017). Instrumen yang digunakan pada penelitian ini yaitu berupa Annual Report, daftar tabel laporan keuangan dan harga saham close PT. Astra Graphia Tbk. dengan teknik pengumpulan data yaitu: Studi pustaka dan Dokumentasi.

\section{TEKNIK ANALISA DATA \\ Uji Asumsi Klasik \\ Uji Normalitas}

Alat analisis yang digunakan dalam penelitian ini kali ini adalah uji Kolmogorov-Smirnov (uji KS) dengan menggunakan bantuan program statistic SPSS. Dimana dengan standar pengambilan keputusan yaitu jika probabilitas lebih besar dari 0,05 maka diterima atau normal tetapi jika probabilitas kurang dari 0,05 maka ditolak yang berarti variabel tidak berdistribusi normal.

\section{Uji Multikolinearitas}

Uji multikolinieritas dilakukan dengan melihat nilai tolerance dan uji multikolinieritas VIF. Dengan standar nilai tolerance maupun nilai VIF mendekati atau berada disekitar angka 1 artinya antara variabel bebas tidak terjadi multikolinieritas tetapi jika nilai VIF > 10 artinya variabel tersebut mempunyai masalah multikolinieritas dengan variabel bebas lainnya.

\section{Uji Heteroskedastisitas}

Standar nilai probabilitas signifikansinya di atas tingkat kepercayaan 5\% atau 0.05 maka tidak terjadi heteroskedastisitas.

\section{Uji Autokorelasi}

Alat analisis yang digunakan adalah uji Durbin-Watson. Gejala autokorelasi ini dapat dideteksi dengan menggunakan durbin-watson test melalui nilai Durbin Watson yang diperoleh, yang berpedoman pada angka skala $d l, d u, 4-d u$, dan 4- $d l$. Pedoman pengambilan keputusan menurut (Ghozali, 2016) adalah sebagai berikut:

- Bila nilai Durbin Watson terletak diantara batas atas, yaitu antara du dan 4-du maka koefisien autokorelasi sama dengan nol yang berarti tidak terjadi autokorelasi.

- Bila nilai Watson terletak lebih rendah dari batas bawah yaitu dl maka koefisien autokorelasi lebih besar dari nol yang berarti terjadi autokorelasi positif.

- Bila nilai Durbin Watson lebih besar dari 4-dl, maka koefisien autokorelasi lebih kecil dari nol yang berarti terjadi autokorelasi negatif.

- Bila nilai Durbin Watson terletak diantara batas atas dan batas bawah, yaitu antara du dan dl atau antara 4-du dan 4-dl, maka koefisien autokorelasi.

\section{Analisis Regresi Linear Berganda}

Model yang digunakan persamaan analisis regresi berganda seperti :

$$
\mathrm{Y}=\alpha+\beta 1 \mathrm{DER}+\beta 2 \mathrm{ROE}+\beta 3 \mathrm{CR}+\beta 4 \mathrm{PER}+\mathrm{e}
$$

\section{Uji hipotesis}

- Analisis korelasi berganda

Analisis korelasi bertujuan untuk mengukur kekuatan asosiatif (hubungan) linear antara dua variabel. Korelasi juga tidak menunjukkan hubungan fungsional. Dengan kata lain, analisis korelasi tidak membedakan antara variabel dependen dengan variabel independen (Sugiyono, 2017). 
- $\quad$ Koefisien Determinasi $\left(\mathrm{R}^{2}\right)$

Rumusnya sebagai berikut:

$\mathrm{KD}=\left(\mathrm{R}^{2}\right) \times 100 \%$

Keterangan:

$\mathrm{KD}=$ Koefisien Determinasi

$\mathrm{R}=$ Koefisien korelasi berganda

- $\quad$ Uji Hipotesis (Uji T)

Pengujian yang menunjukkan seberapa jauh pengaruh variabel independen secara individual dalam menerangkan variasi dependen (Ghozali, 2016).

- $\quad$ Uji Hipotesis (Uji F)

Uji f digunakan untuk menguji apakah variabel bebas secara bersama - sama berpengaruh terhadap variabel terikat. Untuk melihat pengaruh secara simultan atau secara bersama - sama terhadap variabel terikat (Ghozali, 2016).

\section{HASIL DAN PEMBAHASAN \\ Uji Asumsi Klasik \\ Uji Normalitas}

Pada penelitian ini alat analisis yang dipakai adalah adalah uji Kolmogorov-Smirnov (uji K-S) dengan memakai bantuan aplikasi dari program statistic SPSS. yaitu dengan menetapkan standarnya sebesar harus lebih dari 0,05 tetapi jika kurang dari angka 0,05 maka data yang diteliti tidak normal.

\begin{tabular}{|c|c|c|}
\hline \multirow{2}{*}{\multicolumn{2}{|c|}{$\begin{array}{l}\text { One-Sampel } \\
\text { Kolmogrov-Smirnov } \\
\text { Test }\end{array}$}} & Unstandized \\
\hline & & Residual \\
\hline \multicolumn{2}{|l|}{$\mathrm{N}$} & 15 \\
\hline \multirow{2}{*}{$\begin{array}{l}\text { Normal } \\
\text { Parameters }{ }^{\mathrm{a}, \mathrm{b}}\end{array}$} & Mean & .0000000 \\
\hline & $\begin{array}{l}\text { Std. } \\
\text { Deviation }\end{array}$ & .35562934 \\
\hline \multirow{3}{*}{$\begin{array}{l}\text { Most Extreme } \\
\text { Differences }\end{array}$} & Absolute & .094 \\
\hline & Positive & .094 \\
\hline & Negative & -.093 \\
\hline \multicolumn{2}{|l|}{ Test Statistic } & .094 \\
\hline \multicolumn{2}{|c|}{ Asymp. Sig. (2-tailed) } & $.200^{\mathrm{c}, \mathrm{d}}$ \\
\hline
\end{tabular}

Pada tabel di atas dapat kita lihat bahwa nilai asymp sig sebesar 0,200 yang berarti melebihi dari standar 0,05 dan asumsi normalitas terpenuhi.

\section{Uji Multikolinearitas}

Pada pengujian ini hal yang harus diperhatikan adalah hanya berfokus pada nilai dari tolerance dan VIF. Jika nilai tolerance dan VIF berada diseputaran angka 1 maka ditarik kesimpulan antara variabel bebas tidak terjadi multikolinieritas tetapi jika nilai VIF > 10 berarti antara variabel tersebut mempunyai masalah multikolinieritas dengan variabel bebas lainnya.

Tabel 2 Asumsi Multikolinearitas

\begin{tabular}{|c|c|c|c|c|c|c|c|c|}
\hline \multirow{2}{*}{\multicolumn{2}{|c|}{ Model }} & \multicolumn{2}{|c|}{$\begin{array}{l}\text { Unstandardized } \\
\text { Coefficients }\end{array}$} & \multirow{2}{*}{$\begin{array}{c}\text { Standardized } \\
\text { Coefficients } \\
\text { Beta }\end{array}$} & \multirow{2}{*}{$\mathrm{T}$} & \multirow{2}{*}{ Sig. } & \multicolumn{2}{|c|}{$\begin{array}{l}\text { Collinearity } \\
\text { Statistics }\end{array}$} \\
\hline & & B & $\begin{array}{c}\text { Std. } \\
\text { Error }\end{array}$ & & & & Tolerance & VIF \\
\hline \multirow{5}{*}{1} & (Constant) & 1.150 & 1.375 & & .837 & .422 & & \\
\hline & DER & -.393 & .565 & -.175 & -.695 & .503 & .316 & 3.169 \\
\hline & ROE & .006 & .023 & .055 & .237 & .817 & .379 & 2.637 \\
\hline & CR & -.664 & .390 & -.571 & 1.705 & .119 & .179 & 5.597 \\
\hline & PER & .261 & .053 & .881 & 4.891 & .001 & .616 & 1.623 \\
\hline
\end{tabular}

Sumber : output spss 23 
Dapat kita lihat dari data diatas bahwa nilai VIF untuk ke 4 variabel X masing-masing kurang dari 10 sehingga dapat ditarik kesimpulan bahwa tidak terjadi multikolinearitas.

\section{Uji Heteroskedastisitas}

Pada penelitian ini masih menggunaka bantuan program spss dimana teknik pengambilan keputusannya adalah dengan melihat grafik plot yang tebentuk dari pengujian heteroskedastisitas apakah membentuk pola tertentu atau tidak. Karena jika membentuk pola tertentu maka maka pengujian heteroskedastisitas terpenuhi.

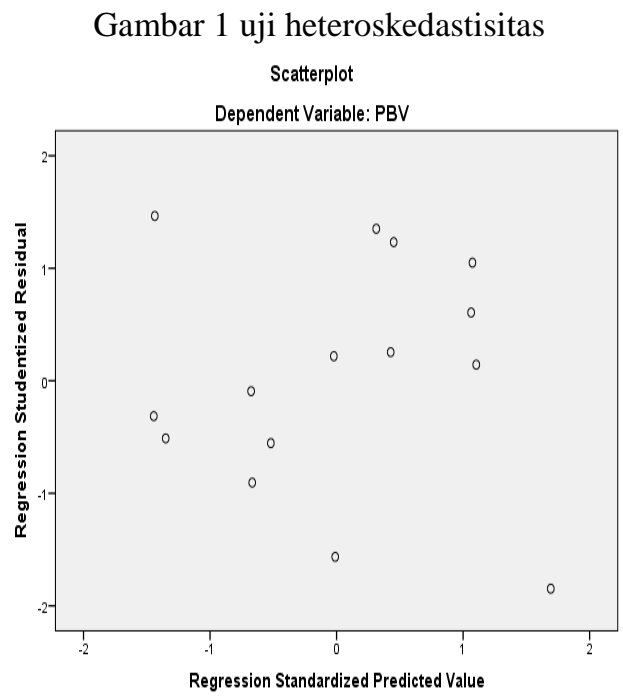

Sumber: Output spss 23

Dapat kita lihat secara bersama bahwa sanya grafik plot diatas tidak membentuk pola tertentu yang berarti bahwa uji heteroskedastisitas tidak terpenuhi.

\section{Uji Autokorelasi}

Pada penelitian ini menggunakan bantuan program spss yaitu dengan alat analisis yang di sebut uji Durbin-watson dimana ada 4 standar pengambilan keputusan yaitu (Ghozali, 2016).

1. Jika nilai DW diantara batas atas yaitu antara nilai du dan 4-du maka tidak ada gejala autokoresi

2. Jika nilai DW lebih rendah dari batas bawa dl maka ada gejala positif dari autokorelasi

3. Jika nilai DW lebih besar dari 4-dl maka ada gejala negative dari autokoresi

4. Jika nilai DW berada ditengah-tengah batas bawah dan batas atas maka terjadi gejala koefisien autokorelasi

\begin{tabular}{rrrrrr}
\multicolumn{7}{c}{ Tabel 4 uji autokorelasi } \\
\hline Model & $\mathrm{R}$ & $\begin{array}{c}\mathrm{R} \\
\text { Square }\end{array}$ & $\begin{array}{c}\text { Adjusted } \\
\text { R Square }\end{array}$ & $\begin{array}{c}\text { Std. } \\
\text { Error of } \\
\text { the } \\
\text { Estimate }\end{array}$ & $\begin{array}{c}\text { Durbin- } \\
\text { Watson }\end{array}$ \\
\hline 1 & $.894^{\mathrm{a}}$ & .800 & .720 & .42079 & 1.156 \\
\hline
\end{tabular}

Sumber: Output SPSS 23

Berdasarkan data di atas dapat di tarik kesimpulan bahwa nilai DW berada di antara nilai dl dan du hal ini didasarkan dari dimana nilai $\alpha=5 \%, \mathrm{n}=15$ dan $\mathrm{k}=4$ sehingga diperoleh nilai dl 0,6852 dan du 1,9774. Dikarenakan nilai DW beraada di tengah-tengah dl dan du sehingga tidak dapat di tarik kesimpulnya. Peneliti melakukan alternative yaitu dengan menggunakan pengujian runs test. 
Tabel 5 uji runs test

\begin{tabular}{lr}
\hline & Unstandardized Residual \\
\hline Test Value & .05372 \\
Cases $<$ Test & 7 \\
Value & \\
Cases >= Test & 8 \\
Value & 15 \\
Total Cases & 5 \\
Number of & 5 \\
Runs & -1.597 \\
$Z$ & .110 \\
Asymp. Sig. & \\
(2-tailed) &
\end{tabular}

Dimana standar pengambilan kesimpulanya yaitu jika nilai asymp. Sig kurang dari 0,05 maka autokorelasi terjadi tetapi jikalau asymo. Sig lebih dari 0,05 maka tidak terjadi autokorelasi (Ghozali, 2016) dan data di atas menghasilkan nilai asymp sig sebesar 0,110 yang berarti gejala autokorelasi tidak terpenuhi.

\section{Analisis Regresi Linear Berganda}

Pada analisis ini masih menggunakan bantuan program spss tetapi dengan standar model persamaan sebagai berikut:

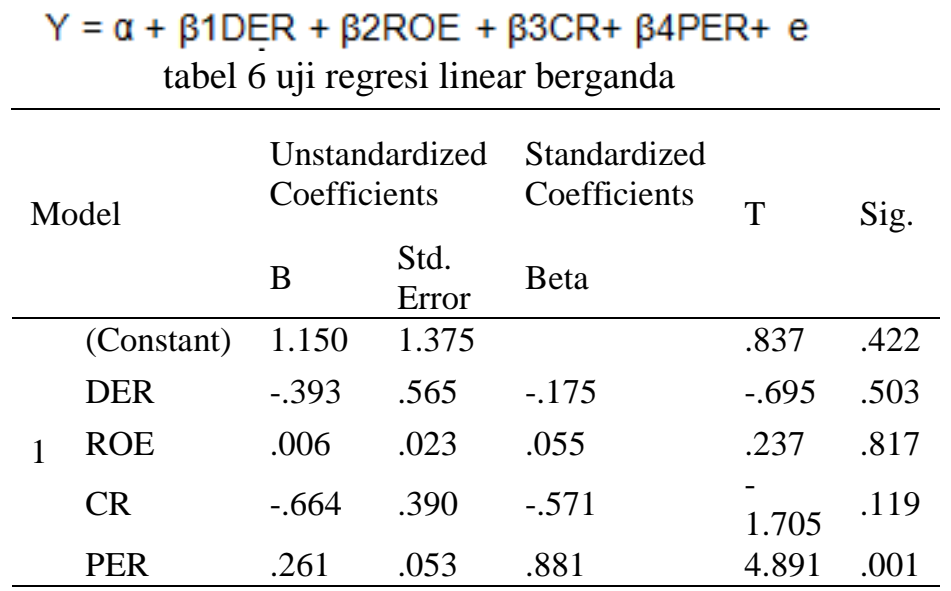

Sumber: otput spss 23

Pengujian ini digunakan untuk mengetahui apakah variabel independen $D E R, R O E, C R, P E R$ berpengaruh terhadap variabel dependen Nilai Perusahaan. Hasil analisis menggunakan tingkat signifikasi sebesar 0,05 pada persamaan regresi, sehingga diperoleh hasil sebagai berikut:

$Y=1,150-0,393 X_{1}+0,006 X_{2}-0,664 X_{3}+0,261 X_{4}+e$

a. Konstanta $\left(\beta_{0}\right)=1,150$

Berarti jika nilai $D E R, R O E, C R, P E R$ dianggap konsisten maka Nilai Perusahaan meningkat sebesar 1,150 tetapi jika nilai dari $D E R, R O E, C R, P E R$ tidak dalam keadaan konsisten maka Nilai Perusahaan akan menurun.

b. Debt to equity ratio $\left(\beta_{1}\right)=-0,393$

Berarti pada saat menurunya nilai dari Debt to equity ratio maka Nilai perusahaan akan ikut menurunan sebesar 0,392 tetapi jika Debt to equity ratio meningkat maka Nilai Perusahaan akan ikut meningkat.

c. Return on equity $\left(\beta_{2}\right)=0,006$

Berarti setiap kenaikan nilai $R O E$ maka Nilai perusahaan akan ikut meningkat sebesar 5,786 tetapi setiap nilai $R O E$ menurun maka Nilai perusahaan juga ikut menurun 
d. Current Ratio $\left(\beta_{3}\right)=-0,664$

Berarti setiap penurunan nilai $C R$ maka Nilai perusahaan akan ikut menurunan sebesar 0,664 tetapi jika $C R$ meningkat maka Nilai Perusahaan ikut meningkat.

e. Price Earning Ratio $\left(\beta_{4}\right)=0,261$

Berarti setiap kenaikan nilai PER maka Nilai perusahaan akan ikut meningkat sebesar 0,261 tetapi jika $P E R$ menurun maka Nilai Perusahaan ikut menurun.

\section{Uji Hipotesis}

\section{Analisis korelasi berganda}

Pada analisis ini masih menggunakan bantuan program spss dimana analisis korelasi berganda mengukur seberapa besar tingkat keeratan hubungan antara variable bebas dan terikat.

Tabel 7 pengujian korelasi berganda

\begin{tabular}{|c|c|c|c|c|c|c|c|c|c|}
\hline \multirow[b]{2}{*}{ Model } & \multirow[b]{2}{*}{$\mathrm{R}$} & \multirow[b]{2}{*}{$\begin{array}{c}\mathrm{R} \\
\text { Square }\end{array}$} & \multirow[b]{2}{*}{$\begin{array}{l}\text { Adjusted } \\
\text { R Square }\end{array}$} & \multirow{2}{*}{$\begin{array}{l}\text { Std. } \\
\text { Error of } \\
\text { the } \\
\text { Estimate }\end{array}$} & \multicolumn{5}{|c|}{ Change Statistics } \\
\hline & & & & & $\begin{array}{c}\mathrm{R} \\
\text { Square } \\
\text { Change }\end{array}$ & $\begin{array}{c}\mathrm{F} \\
\text { Change }\end{array}$ & df1 & df2 & $\begin{array}{l}\text { Sig. F } \\
\text { Change }\end{array}$ \\
\hline 1 & $.894^{\mathrm{a}}$ & .800 & .720 & .42079 & .800 & 9.997 & 4 & 10 & .002 \\
\hline
\end{tabular}

Sumber: output spss 23

Berdasarkan data di atas dapat di tarik kesimpulan bahwa tingkat keeratan hubungan Debt to Equty, Return on Equty, Current Ratio, Price Earning Ratio terhadap nilai perusahaan (PBV) berada pada tingkat yang sangat kuat di lihat dari angka $R=0,894$.

Koefisien Determinasi $\left(\mathrm{R}^{2}\right)$

Merupakan alat analis yang menguji seberapa besar porsentase (\%) keeratan hubungan antara variabel $\mathrm{X}$ dan Y. Dengan mengunakan rumus : KD $=\left(\mathrm{R}^{2}\right) \times 100 \%$

$$
\mathrm{R}=\text { Koefisien korelasi berganda }
$$

Pada tabel 7 diatas dapat kita lihat bersama bahwa nilai dari $\mathrm{R}^{2}$ yaitu 0,800 kemudian dikali dengan $100 \%$ sehingga mengahasilkan nilai keeratan sebesar $80 \%$ sedangkan untuk sisanya yang $20 \%$ bersumber dari hal yang lain yang tidak diteliti oleh peneliti.

\section{Uji hipotesis $\mathbf{t}$}

Ini merupakan pengujian yang mengukur hubungan perindividual antara variabel $\mathrm{X}$ dengan variabel Y (Ghozali, 2016).

Tabel 8 uji-T

\begin{tabular}{|c|c|c|c|c|c|c|}
\hline \multirow{2}{*}{\multicolumn{2}{|c|}{ Model }} & \multicolumn{2}{|c|}{$\begin{array}{c}\text { Unstandardized } \\
\text { Coefficients }\end{array}$} & \multirow{2}{*}{$\begin{array}{c}\text { Standardized } \\
\text { Coefficients } \\
\text { Beta }\end{array}$} & \multirow{2}{*}{$\mathrm{t}$} & \multirow{2}{*}{ Sig. } \\
\hline & & B & $\begin{array}{l}\text { Std. } \\
\text { Error }\end{array}$ & & & \\
\hline \multirow{5}{*}{1} & (Constant) & 1.150 & 1.375 & & .837 & .422 \\
\hline & DER & -.393 & .565 & -.175 & -.695 & .503 \\
\hline & ROE & .006 & .023 & .055 & .237 & .817 \\
\hline & $\mathrm{CR}$ & -.664 & .390 & -.571 & -1.705 & .119 \\
\hline & PER & .261 & .053 & .881 & 4.891 & .001 \\
\hline
\end{tabular}

Sumber : Output SPSS 23

Karena standar pengambilan kesimpulan dari uji hipotesis T terdiri dari 2 opsi yaitu:

1. Dimana jika $-\mathrm{T}_{\text {tabel }}<\mathrm{T}_{\text {hitung }}<\mathrm{T}_{\text {tabel }}$ maka $\mathrm{H}_{0}$ diterima

2. Dimana Jika $\mathrm{T}_{\text {hitung }}<-\mathrm{T}_{\text {tabel }}$ dan $\mathrm{T}_{\text {hitung }}>\mathrm{tT}_{\text {tabel }}$ maka $\mathrm{H}_{0}$ ditolak. 


\section{Uji hipotesis F}

Ini merupakan pengujian yang mengukur hubungan keseluruhaan antara variabel $\mathrm{X}$ dengan variabel Y (Ghozali, 2016).

Tabel 9 uji anova

\begin{tabular}{llrrrrr}
\hline Model & & Sum of Squares & df & Mean Square & F & \multicolumn{1}{c}{ Sig. } \\
\hline 1 & Regression & 7.075 & 4 & 1.769 & 9.957 & $.002^{\mathrm{b}}$ \\
& Residual & 1.776 & 10 & .178 & & \\
& Total & 8.851 & 14 & & & \\
\hline
\end{tabular}

a. Dependent Variable: NILAI PERUSAHAAN

b. Predictors: (Constant), PER, ROE, DER, CR

Sumber: output spss 23

Sama seperti uji T sebelumnya Uji F juga memiliki 2 standar pengambilan keputusan antara lain:

1. Jika $\mathrm{F}$ hitung $<\mathrm{F}$ tabel maka diterimalah $\mathrm{H}_{0}$

2. Jika $\mathrm{F}$ hitung $>\mathrm{F}$ tabel maka ditolaklah $\mathrm{H}_{0}$

Dari data di atas dapat ditarik kesimpulan bahwa nilai $\mathrm{F}$ tabel 3,48 nilai ini di dapatkan dari df1=k1 dan df $2=n-k$ sehingga df $1=5-1$ dan df2=15-5=10 (cek tabel F). itulah asal usul nilai $F$ tabel 3,48 sehingga peneliti menarik kesimpulan bahwa pada variabel DER, CR, PER dan ROE telah terjadi pengaruh signifikan secara simultan atau bersama-sama padan nilai perusahaan.

\section{PEMBAHASAN}

\section{Pengaruh Debt to Equity Ratio terhadap Nilai Perusahaan}

Debt to Equity Ratio adalah sebuah ratio yang mengambarkan sampai seberapa besar perusahaan dapat meminimalisir hutangnya untuk pihak diluar dari modal perusahaan sendiri, semakin kecil nilai dari DER maka rasio dikatakan bagus. Dalam penelitian ini Debt to Equity Ratio tidak berpengaruh secara parsial terhadap nilai perusahaan karena nilai modal lebih besar dari pada hutang, PT. Astra Graphia Tbk. belum bisa mununjukan kemampuan perusahaan mereka dalam mengoptimalkan penggunaan hutang untuk meningkatkan Nilai Perusahaan. Bagi seorang investor besar kecilnya sebuah hutang tidak terlalu diperhatika oleh mereka karena mereka lebih fokus melihat bagaimana manajemen perusahaan mengunakan dana yang ada dengan efektif dan efisien untuk menambah nilai perusahaan mereka. Penelitian ini sesuai dengan sesuai dengan penelitian yang dilakukan oleh (Anggraini, 2015) Analisis pengaruh PER (Price Eraning Ratio), DER (Debt To Equity Ratio), ROA (Return On Equity), CR (Current Ratio) dan Firm Size Terhadap Nilai Perusahaan (PBV) Pada perusahaan Sektor Estate dan Building Construction yang terdaftar di bursa efek Indonesia.

\section{Pengaruh Return on Equity terhadap nilai perusahaan}

ROE (Return On Equity) menunjukan seberapa mampu sebuah perusahaan mendapatkan laba sesudah dibebankan pajak dari mengalokasikan modal sendiri sebuah perusahaan Menurut (Nurlia dan Trifina, 2018). Dalam penelitian kali ini Return On Equity tidak berpengaruh secara parsial terhadap nilai perusahaan karena menurut pendapat investor saat melakukan investasi pada sebuah perusahaan tidak hanya melihat tingkat pengembalian yang tinggi melainkan investor melihat lingkungan investasi, apabila tingkat pengembalianya tinggi tetapi iklim investasi tidak baik maka investor akan mempertimbangkan suatu investasi. Penelitian ini sesuai dengan penelitian (Haerudin \& Marcellia, 2019) pengaruh struktur modal, profitabilitas dan pertumbuhan perusahaan terhadap nilai perusahaan pada perusahaan perbankan yang terdaftar di bursa efek Indonesia.

\section{Pengaruh Curren ratio terhadap nilai perusahaan}

Current Ratio merupakan rasio yang mengambarkan kemampuan current asset sebuah perusahaan yang bisa dipakai untuk memenuhi current liabilities. Dalam penelitian ini Current ratio tidak berpengaruh secara parsial terhadap nilai perusahaan, Maka semakin tinggi nilai dari Current ratio dapat dikatakan adanya dana yang mengangur yang berarti adanya penurunan laba karena aktiva yang diperoleh lebih 
banyak dipergunakan untuk membayar hutang jangka pendek dan tidak dapat dijadikan untuk patokan pengambilan keputusan berinvestasi dan tidak memiliki pengaruh terhadap nilai perusahaan. Penelitian ini sejalan dengan penelitian (Haerudin \& Marcellia, 2019) Pengaruh Struktur Modal, Profitabilitas dan Pertumbuhan Perusahaan terhadap Nilai Perusahaan pada perusahaan perbankan yang terdaftar di bursa efek Indonesia.

\section{Pengaruh Price Earning Ratio terhadap nilai perusahaan}

Price Earning Ratio yaitu sebuah rasio yang mengambarkan perbedaan antara penghasilan yang masuk dengan nilai dari saham di tawarkan. Dalam penelitian ini Price Earning Ratio berpengaruh secara parsial terhadap nilai perusahaan hal ini menujuakan bahwa Price Earning Ratio merupakan indikator yang menujukan kekuatan financial perusahaan, dengan memperhatikan nilai dari Price Earning Ratio maka dapat melihat seberapa besar laba yang diperoleh dari penjualan saham pada investor dan investor juga dapat melihat Price Earning Ratio sebagai salah satu indikator pengambilan keputusan untuk berinvestasi. Penelitian ini sejalan dengan sesuai dengan penelitian (Arif, 2015) Pengaruh Stuktur Modal, ROA (Return On Equity), Likuiditas, dan Growth Opportunity Terhadap Nilai Perusahaan Pada Perusahaan Jasa Yang Terdaftar Di Bursa Efek Indonesia.

\section{Pengaruh Price Earning Ratio, Return On Equity, Debt To Equity dan Curren Ratio terhadap Nilai Perusahaan}

Dalam penelitian ini Price Earning Ratio, Return On Equity, Debt to Equity dan Current Ratio berpengaruh secara simultan terhadap Nilai Perusahaan hal ini berarti bahwa semua variabel independen berpengaruh secara bersama terhadap variabel dependen.

\section{KESIMPULAN}

DER (Debt to equity ratio) tidak berpengaruh secara parsial terhadap nilai perusahaan pada PT. Astra Graphia Tbk. karena nilai modal lebih besar dari pada hutang, PT. Astra Graphia Tbk. belum bisa mununjukan kemampuan perusahaan mereka dalam mengoptimalkan penggunaan hutang untuk meningkatkan Nilai Perusahaan. Bagi seorang investor besar kecilnya sebuah hutang tidak terlalu diperhatika oleh mereka karena mereka lebih fokus melihat bagaimana manajemen perusahaan mengunakan dana yang ada dengan efektif dan efisien untuk menambah nilai perusahaan mereka. ROE (Return on equity) tidak berpengaruh secara parsial terhadap nilai perusahaan pada PT. Astra Graphia Tbk. karena menurut pendapat investor saat melakukan investasi pada sebuah perusahaan tidak hanya melihat tingkat pengembalian yang tinggi melainkan investor melihat lingkungan investasi, apabila tingkat pengembalianya tinggi tetapi iklim investasi tidak baik maka investor akan mempertimbangkan suatu investasi. CR (Current ratio) tidak berpengaruh secara parsial terhadap nilai perusahaan pada PT. Astra Graphia Tbk. Maka semakin tinggi nilai dari Current Ratio dapat dikatakan adanya dana yang mengangur yang berarti adanya penurunan laba karena aktiva yang diperoleh lebih banyak dipergunakan untuk membayar hutang jangka pendek dan tidak dapat dijadikan untuk patokan pengambilan keputusan berinvestasi dan tidak memiliki pengaruh terhadap nilai perusahaan. PER (Price Earning Ratio) berpengaruh secara parsial terhadap nilai perusahaan pada PT. Astra Graphia Tbk. hal ini menujuakan bahwa Price Earning Ratio merupakan indikator yang menujukan kekuatan financial perusahaan, dengan memperhatikan nilai dari Price Earning Ratio maka dapat melihat seberapa besar laba yang diperoleh dari penjualan saham pada investor dan investor juga dapat melihat Price Earning Ratio sebagai salah satu indikator pengambilan keputusan untuk berinvestasi. PER (Price Earning Ratio), ROE (Return On Equity), DER (Debt To Equity) dan CR (Current Ratio) berpengaruh secara simultan terhadap Nilai Perusahaan hal ini berarti bahwa semua variabel independen berpengaruh secara bersama terhadap variabel dependen.

\section{SARAN}

1. Saran bagi perusahaan dan investor yaitu hedaknya memperhatikan profit perusahaan, tingkat pengembalian laba yang tinggi, dan kemampuan perusahaan dalam membayar hutang dengan menggunakan modal sendiri. Karena berdasarkan penelitian ini para investor tidak memperhatikan aspek-aspek penting ini. 
2. Saran teoritis yaitu diharapkan kepada para peneliti selanjutnya yang ingin membahas pokok pembahasan seperti ini untuk menambah variabel lain misalnya ukuran perusahaan dan Invesment Opportunity Set (IOS), Populasi seluruh perusahaan jasa dibursa efek indonesia dan sampel sesuai dengan kebutuhan penelitian misal 20 atau lebih.

\section{REFERENSI}

Anggraini, R. (2015). Analisis Pengaruh Price Earning Ratio(PER), Debt to Equity Ratio(DER), Return on Equity(ROA), Curren Ratio(CR) dan Firmsize Terhadap Nilai Perusahaan(PBV) pada Perusahaan Sektor Estate dan Building Construction yang terdaftar di bursa efek indonesia(BEI). Skripsi, 1-11.

Arif. (2015). Pengaruh Struktur Modal, Return on Equity, Likuiditas, dan Growth Opportunity terhadap Nilai Perusahaan pada Perusahaan Jasa yang Terdaftar di Bursa Efek Indonesia. Fakultas Universitas Negri Yogyakarta, 1-105.

Fahmi, I. (2015). Manajemen Investasi: Teori dan Soal jawab. Jakarta: Salemba Empat.

Ghozali, I. (2016). Aplikasi Analisis Multivariate dengan Program IBM SPSS 23. Semarang: Badan Penerbit Universitas Diponegoro.

Haerudin, \& Marcelia. (2019). Pengaruh Stuktur Modal Profitabilitas dan Pertumbuhan Perusahaan pada Sektor Perusahaan Perbankan yang terdaftar di BEI 2013-2016. Unismus, 1-16.

Harahap, Sofyan Syafri. (2018). Analisis Kritis Atas Laporan Keuangan. Edisi Keempat Belas. Raja Grafindo Persada, Depok

Lukviarman, N. (2006). Dasar dasar Manajemen Keuangan. padang: Andalas Universitas Press.

Luthfiah, A. \&. (2018). The Effects of Financial Performance Towarrd Firm Value With Ownwrship Structure As Moderating Variable (The Study On Manufacturing Companies Listed In Indonesia Stock Exchange in The Period of 2012-2016). Journal of Business and Behavioural Entrepreneurship, 18-27.

Murhadi, W. (2015). Analisis Laporan Keuangan Proyeksi dan Valuasi Saham. Salemba Empat.

MurhadI, W. (2015). Analisis Laporan Proyeksi dan Valuasi saham. Salemba Empat.

Nurlia dan Trifina, B. w. (2018). Manajemen Keuangan. Kuningan: Nusa Litera Inspirasi.

Nurlia, N. J. (2019). Pengaruh Return on Asset, Return on Equity, Earning Per Share Dan Current Ratio Terhadap Harga Saham Pada Perusahaan Sub Sektor Otomotif Dan Komponen Yang Terdaftar Di Bursa Efek Indonesia. Jurnal GeoEkonomi, 57-73.

Purwanto, P. \&. (2017). Financial performance towards value of firms in basic and chemicals industry. European Research Studies Journal, 443-460.

Salainti, M. L. (2019). Pengaruh Current Ratio, Total Asset Turnover dan Debt to Equity Ratio dan Return on Asset terhadap Nilai Perusahaan. Ilmu dan Riset Manajemen, 1-23. 
Sugiyono. (2017). Metode Penelitian Kuantitatif, Kualitatif dan R\&D . Bandung: Alfabeta cv.

Wahyudiono, B. (2014). Mudah Membaca Laporan Keuangan. jakarta: Raih Asa Sukses (Penebar Swadaya Grup). 